\title{
Lahu Chinese
}

National Cancer Institute

\section{Source}

National Cancer Institute. Lahu Chinese. NCI Thesaurus. Code C158181.

A Chinese person from the Lahu ethnic group. 